The most important stage in the technological operations for grain production is its post-harvest processing. At this stage, the quality of the grain masses is lost because the temperature condition inside bulk grain is almost never checked during temporary storage.

In order to increase the technological efficiency of primary grain processing and storage, an installation has been designed that could preserve the quality of grain at low-capacity enterprises or during temporary storage. As the self-heating of grain during storage is a serious issue, the installation would also help solve the problem related to the temporary lack of storage facilities. Thus, using active grain ventilation makes it possible to improve the resistance of grain masses to storage. The available body of research into energy-saving drying processes, active ventilation, and purification of grain from light impurities mainly resolve highly specialized technological tasks. Of interest are those studies that aim to design and implement the rational equipment structure for the active ventilation and cleaning of grain from light impurities, which make it possible to prac tically execute non-stationary modes. This paper considers the efficiency of active ventilation and the reduction of energy costs depending on the installation's structural parameters; specifically, the height of the chamber and the speed of supply of warm air are selected. The height of the working chamber of $1 \mathrm{~m}$ and the air velocity of 1.1-1.4 $\mathrm{m} / \mathrm{s}$ have been experimentally proven and theoretically substantiated

Keywords: active ventilation, chamber height, feed speed, intergrain space, specific energy cost
UDC $664.6 / .7$

DOI: $10.15587 / 1729-4061.2022 .253038$

\title{
DEVELOPING A STATISTICAL MODEL FOR THE ACTIVE VENTILATION OF A GRAIN LAYER WITH HIGH MOISTURE CONTENT
}

\author{
Ardak Askarov
}

Doctoral Student

Department of Mechanization and Automation of Food Production*

Dinara Tlevlessova

Corresponding author

$\mathrm{PhD}$, Associate Professor

Department of Food Technology*

E-mail: tlevlessova@gmail.com,dinusina@mail.ru

A lexander Ostrikov

Doctor of Technical Sciences, Professor

Department of Technologies of Fats,

Processes and Apparatus for Chemical and Food Production Federal State Budget Educational Institution of Higher Education «Voronezh State University of Engineering Technologies»

(FSBEI HE «VSUET»)

Revolution ave., 19, Voronezh, Russian Federation, 394036

Yermek Shambulov

$\mathrm{PhD}$, Aassociate Professor

Department of Machines and Devices of Production Processes*

A inura Kairbayeva

$\mathrm{PhD}$, Associate Professor

Department of Mechanization and Automation of Production Processes*

*AImaty Technological University

Tole bi str., 100, Almaty, Republic of Kazakhstan, 050012

\section{Introduction}

The cultivated land in the Republic of Kazakhstan is 272.5 million hectares, including 21.4 (8.8 \%) million hectares for arable land. Grain crops occupy 13.5 million hectares, including wheat - 105 million hectares, rye -0.07 million hectares.

The Republic of Kazakhstan is a major producer of spring wheat grain, including strong and hard varieties that are raw materials for making high-quality bakery, confectionery products, the best varieties of pasta and cereals.
The main grain producers in the world are the USA, China, and India, which in 2010 produced $47.1 \%$ of the world gross grain harvest, including China - $20.1 \%$ (479.7 million tons), the USA - $16.2 \%$ (401.7 million tons), and India $-10.8 \%$ (267.8 million tons). For per capita production, the countries are distributed in a different order. More than one ton of grain per capita is traditionally produced by the United States $(1,213 \mathrm{~kg})$; in China, this figure is only $321 \mathrm{~kg}$, in India $-213 \mathrm{~kg}$. At the same time, it exceeds one ton in Australia (1,741 kg), Hungary $(1,653 \mathrm{~kg})$, Canada $(1,575 \mathrm{~kg})$, France $(1,049 \mathrm{~kg})$, and other grain-producing countries. 
Grain production in Kazakhstan is an export-oriented industry with more than $30 \%$ of the harvest delivered abroad. However, in recent years, the decline in the quality of wheat has seriously affected its competitiveness. This is confirmed by the data from the Food Corporation: until 2011, the grain harvest in Kazakhstan consisted almost entirely of high-quality wheat. In 2012-2014, the share of third-class grain at elevators was $70 \%$, in $2015-65 \%$, and in 2016 - only $45 \%$.

In the world, 776.5 million tons of wheat grain were produced in 2021 over an area of 221.9 million hectares, with a yield of 35 quintals per hectare. The world leaders in wheat yield are the following countries: Germany $-75.4 \mathrm{dt} / \mathrm{ha}$, France - 68.0, Egypt - 64.0, China - $57.7 \mathrm{dt} / \mathrm{ha}$. In 2021, the areas occupied by wheat were distributed in the following order: India - 31.4 million hectares, Russia - 28.7, China 23.4, USA - 14.9, Australia - 13.0 million hectares. The total share of these countries in 2021 in the world production of wheat grain was $42 \%$ [1].

The quality of planting material in Kazakhstan and around the world has deteriorated significantly. According to scientists, sowing with low-yielding seeds reduces the yield of wheat by $30 \%$. Thus, the average yield per hectare in 2019 was 12.4 quintals, while in 2017 - 14.4 quintals, in $2018-15.1$.

The most important stage in the technological operations of grain production is its post-harvest processing. According to preliminary information, post-harvest processing accounts for $35-40 \%$ of the total cost. The intensity of grain harvesting always exceeds the capacity of technological equipment for the preliminary and primary processing of grain. As a result, freshly harvested grain accumulates at the sites while undergoing self-heating resulting in quality loss. In the northern regions of the country, grain harvesting lasts for 3-4 weeks. Due to climatic conditions, the humidity and weed content of the incoming grain is in the range of $14-24 \%, 10-16 \%$. The temperature condition inside bulk grain during temporary storage is almost never checked. Clogged and moist grain is spoiled.

In the absence of adapted storage facilities, the use of accepting and ventilation compartments with devices for receiving, active ventilation, and self-unloading would solve the task of ensuring the safety of grain and seeds, both during temporary and long-term storage. There is a large body of research into improving the technological processes of active ventilation and subsequent unloading with aero grooves as part of the KZS-25Sh, KZS-25B assemblies, etc. Modern receiving departments for grain are equipped with aero grooves of both open and closed types, with one or more air supply channels. However, existing shortcomings do not make it possible to use aero grooves more widely. Among the significant disadvantages of aero grooves are uneven unloading over time, high power consumption, and increased dust emission in the area of their operation.

Bringing the grain of post-harvest processing into a stable state that ensures its safety, without the use of active ventilation operations, is impossible. Active ventilation operations are necessary during the period of temporary storage in bulk at adapted sites or containers equipped with technical devices for air distribution. Since one of the most energy-intensive processes in grain production is the drying of grain, the development and implementation of energy-sav- ing technologies for bringing it to the required condition is the most important task at present.

Increasing the share of grain production using technologies that allow effective productivity of grain crops, ensuring safety without loss of quality during transportation of storage, is relevant. The introduction of advanced technologies and the improvement of processes would contribute to the financial stability of agricultural producers and ensure food security. In this regard, work on the search for more advanced technologies and equipment for active ventilation and cleaning of grain from light impurities is relevant.

\section{Literature review and problem statement}

Drying grain in the sun in the field is the best method of conservation but it increases the risk of losses due to birds, rodents, and insects. In addition, harvesting an unripe crop can lead to losses due to mold. Reducing such losses is one of the top priorities.

There is a growing trend of drying with microwaves [2] but there are also conflicting opinions about the dangers of such treatment.

In the global community, there is a trend in the popularization of healthy, natural food. The world's population tends to buy and use less processed, more natural products. As a result, the question arises about the price of processing. Many studies report results on the high cost of convective drying in favor of drying with ultra-high frequencies.

Researchers are working on the use of ultrahigh-frequency radiation. Paper [3] considers the process of heat and moisture exchange during drying using ultra-high frequencies. The result of the cited study is the conclusion that when considering the processes of moisture and heat exchange within one grain, it is necessary to take into consideration the temperature gradient. The systems of equations and temperature distribution plots given in $[4,5]$ cannot be used in the calculations of grain drying using disinfection but can be used in drying without disinfection and additional moisture of the grain. As a result of research into using ultra-high frequencies during grain drying, a system of algebraic equations and transfer functions describing heat and moisture exchange in the grain layer was derived [6]. The disadvantage of the cited papers is the unsuitability of formulas for additional processing processes. There is a problem of calculations of the processes of heat and moisture exchange during grain storage, self-heating, and unevenness of the layer of grain masses.

The disadvantage of the method of microwave drying is the high cost of this method. If a field with a static amplitude distribution is excited in a microwave chamber, then uniform heating of the stationary material that completely fills the chamber volume is impossible [7]. Despite the great variety and wide range of possibilities that modern dryers have, dryers remain the most problematic place of modern production for the storage and processing of grain.

The enterprises use four main methods of convective drying of grain [8]: high-temperature drying, high-temperature drying using active ventilation (two-stage drying), a combination of high-temperature and low-temperature drying, low-temperature drying by active ventilation. 
Of the listed methods of heat treatment, the most common is the method of high-temperature drying of grain crops. The principal difference of this method is that the heating, drying, and cooling of the processed product occurs in one drying plant [9]. A serious disadvantage of high-temperature drying of grain is the opposite directions of gradients of moisture content and temperature during the drying process. The temperature gradient, in this case, prevents moisture from moving from the central layers of the grain to the aleurone layer. The use of high-temperature drying of grain in combination with active ventilation is based on the intensification of the process. Intensification occurs by increasing the efficiency of using thermal diffusion of moisture, the flow of which in the process of cooling the grain coincides with the flow of moisture removed due to the diffusion of moisture. In this case, a distinctive feature of the process course is that high-temperature drying stops at a humidity of up to $2 \%$ exceeding the standard. As a result, there is a thermostating of the grain and a redistribution of the moisture content gradient value in the volume of the grain with subsequent drying at active ventilation units. Thus, the increase in productivity in the operation of the dryer is due to the previously unused reserve of thermal burners. The increase in productivity is also due to the independent drying of the grain mass with its heat (induced by high-temperature drying) for a long time at low temperatures during the thermostating process. With such treatment, the differences in the gradient of moisture content in the volume of the grain are neutralized, the moisture content field is leveled, and the magnitude of the volumetric-tense state in the plant tissues of the grain is reduced. This feature of the process can be especially useful when working with strong and valuable wheat, as well as with corn grain, which is subject to intense cracking, especially in the process of heat treatment using high temperatures [10]. It was established that the throughput of the periodic grain installation is a function of the capacity of the deposition hopper, the speed of contact mass transfer, the number of cycles, and the unevenness of the initial moisture content of the grain. It was calculated that the capacity of the deposition hopper is equal to the product of the original unevenness of drying and the capacity of the drying chamber, divided by the contact mass transfer rate. An economic inspection of grain drying with unequal initial humidity was carried out in [11].

There are also oscillating methods of drying grain, which make it possible to reduce the cost of heat for drying. These modes provide for periodic cooling of the grain, which makes it possible to increase the temperature of the drying agent and reduce heat consumption. However, a periodic cooling of the grain with unheated air often reduces the effect of the oscillating regime. The pulse mode, unlike the oscillating one, is characterized only by a decrease in the supply of liquid fuel to the dryer and cooling of the grain by an amount close to the theoretical one, which reduces heat loss and increases drying efficiency. Mathematical methods for calculating the temperature and duration of exposing the grain to a weakly heated drying agent are proposed in [12].

Paper [13] reports the results of research into the development of an active ventilation unit and provides a classification of types and bunkers of active ventilation.
It is shown that the selection of the height of the ventilated zone is important for the efficiency of drying and cleaning grain masses from dust. However, the issues related to the reduction of unit costs with active ventilation remained unresolved. The reason for this may be objective difficulties associated with the design and energy costs for mixing the grain mass and blowing. There are many options for overcoming these difficulties but all of them are intended for large storage facilities and are not suitable for low-capacity enterprises. An alternative option is to design an active ventilation unit with high efficiency by using mathematical analysis. The above allows us to assert that it is advisable to conduct a study to investigate and search for optimal structural parameters and drying modes during active ventilation.

\section{The aim and objectives of the study}

The purpose of this study is to design a statistical model of active ventilation of the grain layer with high humidity providing for the selection of the optimal ratio of the height of the blown zone. This would make it possible to reduce specific energy costs.

To accomplish the aim, the following tasks have been set:

- to substantiate and select rational modes of the active ventilation process for implementing them in the proposed design of the installation for active grain ventilation;

- to substantiate the height of the chamber.

\section{The study materials and methods}

The scheme of the experimental installation is shown in Fig. 1. The installation consists of housing 1, cover 2, capacitor 3 , suction fan 4 , discharge fan 5 . Discharge fan 5 is designed to supply heated air to the intergrain space through a gas distribution pipe 9 . Heater 6 is designed to heat the air that is supplied through pipeline 8 to the installation. Inside housing 1 , there is a suction spiral tube 7 (made of metal-plastic with an inner diameter of $25 \mathrm{~mm}$ and an outer diameter of $32 \mathrm{~mm}$ ). The airflow blown through blowing fan 5 is heated by heater 6 and then piped to a gas distribution pipe with mesh surface 9 for drying the grain (grain, pos. 10). The airflow temperature is measured after heater 6 at point $\mathrm{T} 1$ and at the suction coil at point T2. The air temperature is regulated by a thermostat, which is installed after the heater in the main pipe. The air velocity for each experiment was measured using the anemometer testo 416 (serial number 03621531, made in Germany, measuring range $-0.6-40 \mathrm{~m} / \mathrm{s})$.

The airflow heated by heater 6 is fed into the gas distribution pipe with mesh surface 9 (the pipe is made of stamped mesh with a diameter of $0.1 \mathrm{~m}$, the diameter of the hole is $2 \mathrm{~mm}$ ). Further, the airflow penetrates the intergrain space at a speed of $0.6 \mathrm{~m} / \mathrm{s}, 1.0 \mathrm{~m} / \mathrm{s}, 1.4 \mathrm{~m} / \mathrm{s}$ (according to the planning matrix). Next, the air is sucked in by spiral tube 7 and removed from the unit. In the suction spiral, on the inside, there are drilled slits measuring $2 \times 15 \mathrm{~mm}$ on the side of the gas distribution pipe.

Temperature control is carried out using a thermostat; the airspeed is regulated by a gate that is installed on the suction side of the blower fan. 


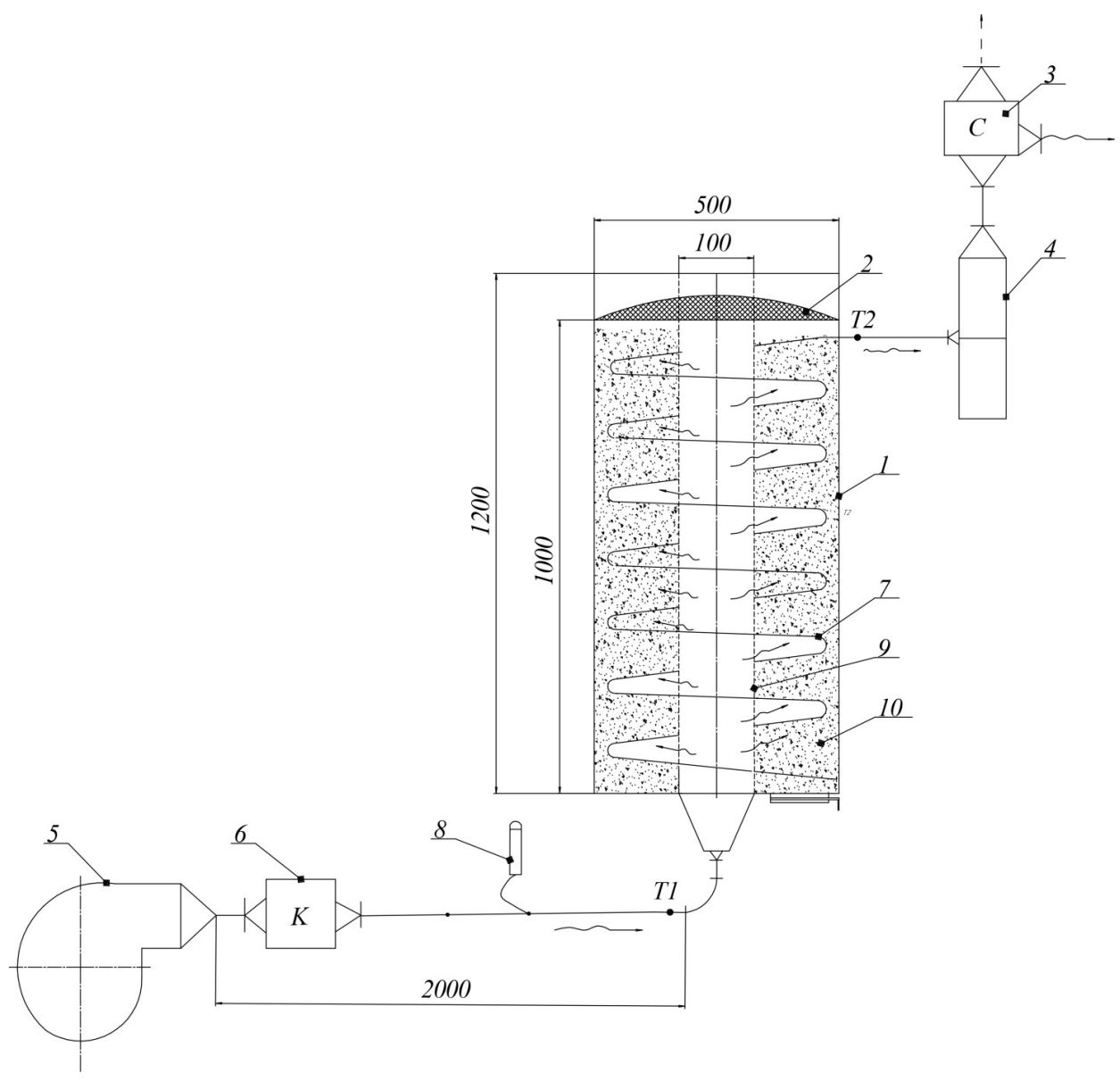

Fig. 1. Experimental installation for active grain ventilation: 1 - housing; 2 - cover; 3 - capacitor; 4 - suction fan; 5 - blowing fan; 6 - heater; 7 - suction spiral tube; 8 - pipeline; 9 - gas distribution pipe with a mesh surface; 10 - wheat grain

\subsection{Research methods}

The principle of operation of the installation (Fig. 2-4): the wheat grains weighing $74 \mathrm{~kg}$, moistened to a humidity of $18 \%$, are loaded into housing 1 of the installation. At a height of 0.6 meters, $74 \mathrm{~kg}$ of the grain reach cover 2 . Cover 2 is then closed tightly. Spiral suction pipe 7 is in the grain. After that, heater 6 is turned on (to obtain the specified temperature regimes of $65^{\circ} \mathrm{C}, 75^{\circ} \mathrm{C}$, $85^{\circ} \mathrm{C}$ ). Supercharger fan 5 and parallel suction fan 4 are then switched on.

Fig. 2 shows a photo of an experimental installation for drying grain with active ventilation.

The air velocity and airflow were measured using the portable digital anemometer testo 416 (serial number 03621531, made in Germany). This windmill-type anemometer is a digital measuring instrument used to measure airflow velocity.

The experiment is conducted according to the planning matrix.

- the diameter (cylinder) of the silo $D=0.5 \mathrm{~m}$, height $1,200 \mathrm{~mm}$;

- the diameter of gas distribution pipe 9 with a mesh surface $d=100 \mathrm{~mm}$.
In this study, the optimal height of the blown area was selected in order to increase the efficiency of the installation.

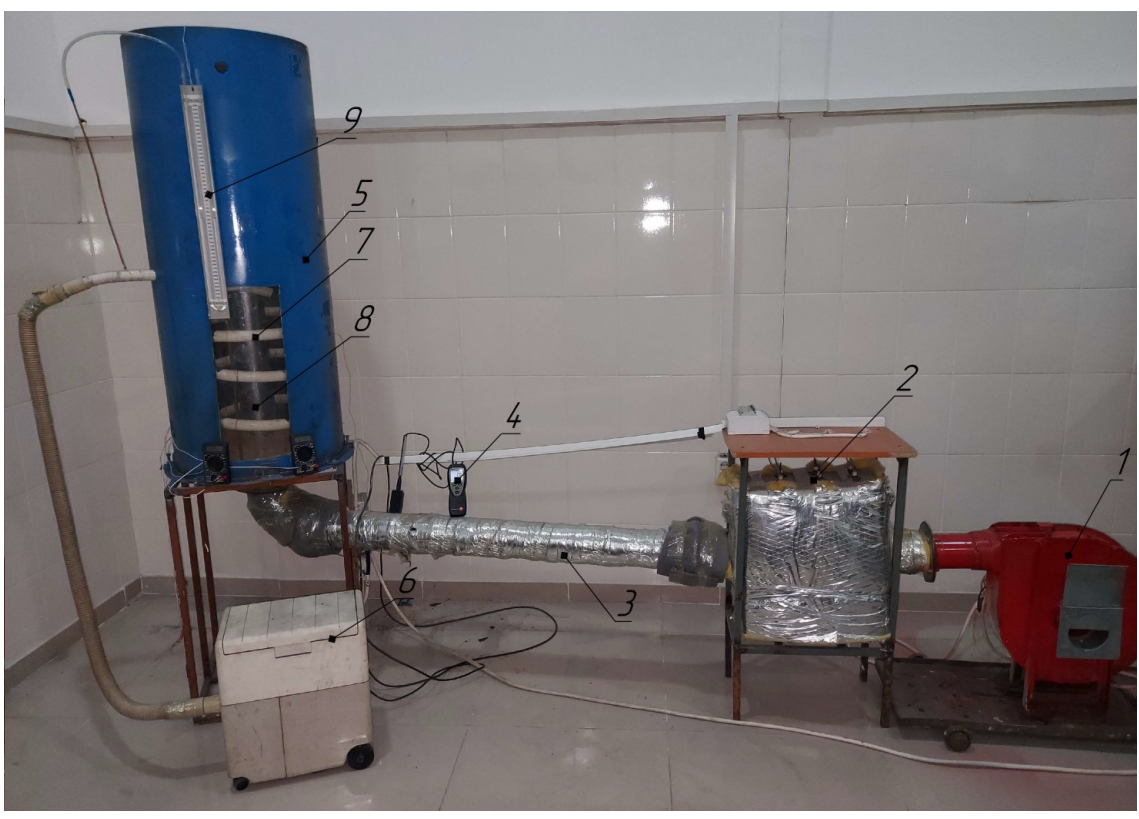

Fig. 2. Experimental installation for drying grain with active ventilation: $1-$ injection fan; 2 - heater; 3 - main pipeline; 4 - anemometer testo 416; 5 - housing; 6 - suction fan; 7 - spiral suction tube; 8 - gas distribution pipe; 9 - mano-vacuum meter for measuring the vacuum value 


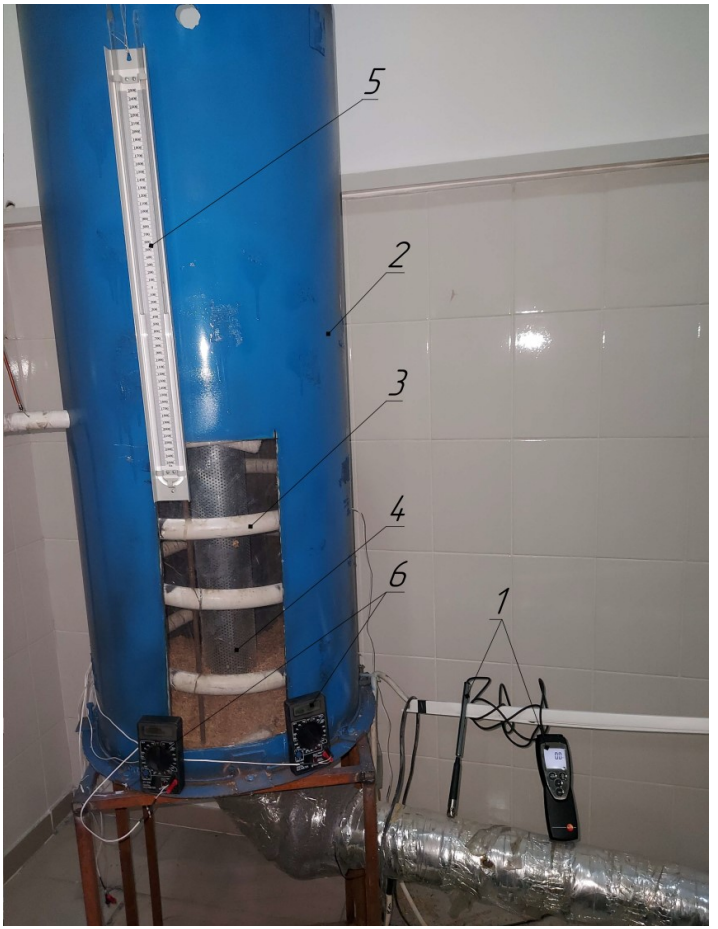

Fig. 3. Photograph of the experimental installation: 1 - anemometer; 2 - housing; 3 - spiral suction pipe;

4 - gas distribution pipe; 5 - mano-vacuum meter for measuring the vacuum value; 6 - STAYER "EXPERT" HIGH

Digital multimeter with a thermocouple

The height of the blown zone is $0.6 ; 0,9 ; 1.2 \mathrm{~m}$.

The diameter of the spiral suction pipe is $32 \mathrm{~mm}$.

The pitch of the spiral should be four times less than the height of the blown zone. For example, if the height is $0.6 \mathrm{~m}$, then the pitch of the spiral is $0.3 \mathrm{~m}$, etc. Slits measuring $2 \times 15 \mathrm{~mm}$ in the spiral suction pipe on the side of the gas distribution pipe are drilled every $5 \mathrm{~cm}$ along the length of the spiral (the length of the spiral pipe is $6 \mathrm{~m}$ ). The dimensions of the slit are selected in such a way that the grains do not pass into them. Blowing duration is $t$ min until the humidity reaches $12 \%$.

The moisture content of the grain entering the elevators from fields for storage typically varies from $13-14 \%$ to $17-18 \%$. Therefore, in the experiments, we varied the initial humidity from $10-11 \%$ to $17-18 \%$. $\mathrm{kJ} / \mathrm{kg}$

Response functions: $\mathrm{y}_{1}-$ specific energy consumption,

Input parameters:

$-\mathrm{x}_{1}$ - air temperature, $t=65-85^{\circ} \mathrm{C}$;

$-\mathrm{x}_{2}-$ air velocity, $v=0.6-1.4 \mathrm{~m} / \mathrm{s}$;

$-\mathrm{x}_{3}-$ distance (the height of the blown zone), $l=0.6-1.2 \mathrm{~m}$.

The value of the relative humidity of the air is neglected due to the insignificance of its change during the period of mass harvesting and the complexity of its regulation.

\section{Results of studying the active ventilation process in the designed installation}

\section{1. Determining the optimal process conditions}

In order to determine the rational parameters of the process of active ventilation of grain in the tank, our studies were conducted in accordance with the rotatable method of experiment planning, which makes it possible to obtain the most accurate mathematical notation of processes.

In accordance with the idea of a step-by-step search, the experiment was conducted in several stages. The number of stages and operations in each of them depended on the results of the previous stage and the ultimate goal of the research. The ultimate goal of this study was to determine the optimal conditions for the course of the process.

The following main factors were chosen: $X_{1}-$ the air velocity $v_{\text {air }}(\mathrm{m} / \mathrm{s})$ at the inlet to the intergrain space; $\mathrm{X}_{2}$ - air temperature, ${ }^{\circ} \mathrm{C} ; \mathrm{X}_{3}$ - distance (the height of the blown zone), $\mathrm{m}$. The selected factors are compatible and are not correlated with each other.

Table 1 gives the main characteristics of the experimental plan and the results of our experimental studies. The total number of experiments, $N=18$; the number of experiments in the center of the plan, $N_{0}=6$; the number of factors, $k=3$; the leverage of the "star" point, $r=1.682$.

Specific energy cost, $\mathrm{kJ} / \mathrm{kg}$, was selected as the response function $Y_{1}$.

Table 1

Main characteristics of the experiment plan

\begin{tabular}{|c|c|c|c|}
\hline \multirow{2}{*}{ Planning condition } & \multicolumn{3}{|c|}{ Factor change limit } \\
\cline { 2 - 4 } & $\mathrm{X}_{1}$ & $\mathrm{X}_{2}$ & $\mathrm{X}_{3}$ \\
\hline Zero level (0) & 1.0 & 75 & 0.9 \\
\hline Variation interval & 0.476 & 11.89 & 0.357 \\
\hline Top level (+1) & 1.238 & 80.945 & 1.078 \\
\hline Lower level (-1) & 0.762 & 69.055 & 0.721 \\
\hline Upper "star" point (+1.682) & 1.4 & 85 & 1.2 \\
\hline Lower "star" point (-1.682) & 0.6 & 65 & 0.6 \\
\hline
\end{tabular}

The studies were conducted as follows. Fig. 1 shows an experimental setup for determining the effects of air velocity $v_{\text {air }}(\mathrm{m} / \mathrm{s})$, the duration of grain treatment with air $\tau_{t r}(\mathrm{~min})$, on the technological efficiency of the process of active grain ventilation with drying if necessary.

Before conducting experiments on the experimental study of the technological efficiency of the installation for active grain ventilation, the parameters of the working agent - air - were adjusted.

The results of our experimental studies on AGV (active grain ventilation) in the container are given in Table 2. For treating our data from experimental studies, the STATISTICA 10 software package was used.

The regression equation in physical variables after the removal of insignificant coefficients is:

$$
\begin{aligned}
& Y_{1}=2498.58-69.0472 \cdot X_{1}-53.0884 \cdot X_{2}- \\
& -416.28 \cdot X_{3}+363.488 \cdot X_{1}^{2}-6.64353 \cdot X_{1} \cdot X_{2}- \\
& -262.3 \cdot X_{1} \cdot X_{3}+0.365153 \cdot X_{2}^{2}+ \\
& +3.29849 \cdot X_{2} \cdot X_{3}+213.386 \cdot X_{3}^{2} .
\end{aligned}
$$

Fig. 4-7 show that the minimum energy consumption is the range of the distance of the blown zone of 1.1-0.9 m, while the air temperature should be $76-80{ }^{\circ} \mathrm{C}$, the speed $1.1-1.4 \mathrm{~m} / \mathrm{s}$.

Given that the factors under study (the air velocity and height of the blown zone) ambiguously affect specific energy costs, the choice of optimal process conditions (by the Harrington method) was carried out. 
Table 2

Planning matrix and results of experimental studies of the process of active grain ventilation

\begin{tabular}{|c|c|c|c|c|c|c|c|c|}
\hline \multirow{3}{*}{ No. of entry } & \multicolumn{6}{|c|}{ Variable parameter } & \multicolumn{2}{|c|}{ Output parameter } \\
\hline & \multicolumn{3}{|c|}{ encoded } & \multicolumn{3}{|c|}{ physical } & \multirow{2}{*}{$\begin{array}{c}\text { experimental } \\
\text { Specific energy cost, } \mathrm{kJ} / \mathrm{kg}\end{array}$} & \multirow{2}{*}{$\begin{array}{c}\text { estimated } \\
\text { Specific energy cost, } \mathrm{kJ} / \mathrm{kg}\end{array}$} \\
\hline & $X_{1}$ & $\mathrm{X}_{2}$ & $\mathrm{X}_{3}$ & $X_{1}$ & $\mathrm{X}_{2}$ & $\mathrm{X}_{3}$ & & \\
\hline 1 & -1 & -1 & -1 & 0.762 & 69.055 & 0.721 & 199.4 & 203.5774 \\
\hline 2 & -1 & -1 & 1 & 0.762 & 69.055 & 1.078 & 213.2 & 203.6219 \\
\hline 3 & -1 & 1 & -1 & 0.762 & 80.945 & 0.721 & 204.3 & 192.332 \\
\hline 4 & -1 & 1 & 1 & 0.762 & 80.945 & 1.078 & 192.3 & 204.1914 \\
\hline 5 & 1 & -1 & -1 & 1.238 & 69.055 & 0.721 & 233.5 & 221.8193 \\
\hline 6 & 1 & -1 & 1 & 1.238 & 69.055 & 1.078 & 164.2 & 176.3802 \\
\hline 7 & 1 & 1 & -1 & 1.238 & 80.945 & 0.721 & 162.3 & 172.0739 \\
\hline 8 & 1 & 1 & 1 & 1.238 & 80.945 & 1.078 & 142.4 & 138.4497 \\
\hline 9 & -1.682 & 0 & 0 & 0.6 & 75 & 0.9 & 205.6 & 208.9671 \\
\hline 10 & 1.682 & 0 & 0 & 1.4 & 75 & 0.9 & 172.6 & 168.9442 \\
\hline 11 & 0 & -1.682 & 0 & 1.0 & 65 & 0.9 & 211.2 & 214.2216 \\
\hline 12 & 0 & 1.682 & 0 & 1.0 & 85 & 0.9 & 176.2 & 172.8903 \\
\hline 13 & 0 & 0 & -1.682 & 1.0 & 75 & 0.6 & 186.2 & 192.0964 \\
\hline 14 & 0 & 0 & 1.682 & 1.0 & 75 & 1.2 & 170.2 & 164.0553 \\
\hline 15 & 0 & 0 & 0 & 1.0 & 75 & 0.9 & 151.5 & 151.5049 \\
\hline 16 & 0 & 0 & 0 & 1.0 & 75 & 0.9 & 151.5 & 151.5049 \\
\hline 17 & 0 & 0 & 0 & 1.0 & 75 & 0.9 & 151.5 & 151.5049 \\
\hline 18 & 0 & 0 & 0 & 1.0 & 75 & 0.9 & 151.5 & 151.5049 \\
\hline
\end{tabular}

Specific energy cost, $\mathrm{kJ} / \mathrm{kg}=2644.1955-55.8968 * \mathrm{x}-630.5344 * \mathrm{y}+$ $+0.3422 * x * x+2.7834 * x * y+208.3048 * y * y$

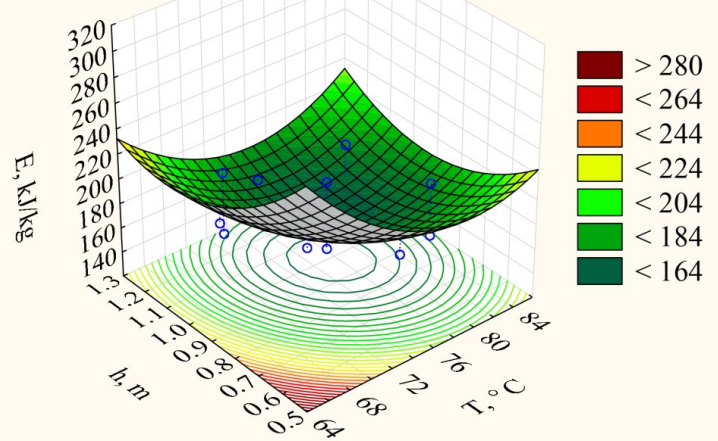

Fig. 4. Dependence of specific energy cost $(E, \mathrm{~kJ} / \mathrm{kg})$ on the height of the blown zone $(h, \mathrm{~m})$ and air temperature $\left(T,{ }^{\circ} \mathrm{C}\right)$

Specific energy cost, $\mathrm{kJ} / \mathrm{kg}=2109.2309+61.3483 * \mathrm{x}-50.0209 * \mathrm{y}+$ $+199.4469 * \mathrm{x} * \mathrm{x}-6.8026 * \mathrm{x} * \mathrm{y}+0.365 * \mathrm{y} * \mathrm{y}$

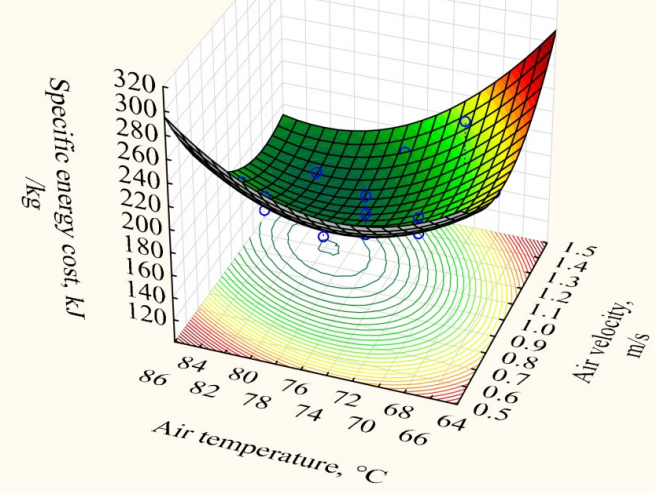

Fig. 5. Dependence of specific energy cost $(E)$ on temperature $T,{ }^{\circ} \mathrm{C}$, and air velocity $(V, \mathrm{~m} / \mathrm{s})$
The task of optimizing the process of active ventilation of grain in the tank was to search for conditions under which specific energy costs are minimal, with a balanced ratio of air velocity and the height of the blown zone (Fig. 5).

3D Surface: v, m/s vs. h, m vs. E, kJ/kg

$\mathrm{E}, \mathrm{kJ} / \mathrm{kg}=357.9278-167.3774 * \mathrm{x}-134.7705 * \mathrm{y}+179.1204 * \mathrm{x} * \mathrm{x}-$ $-267.6569 * x * y+197.5487 * y * y$

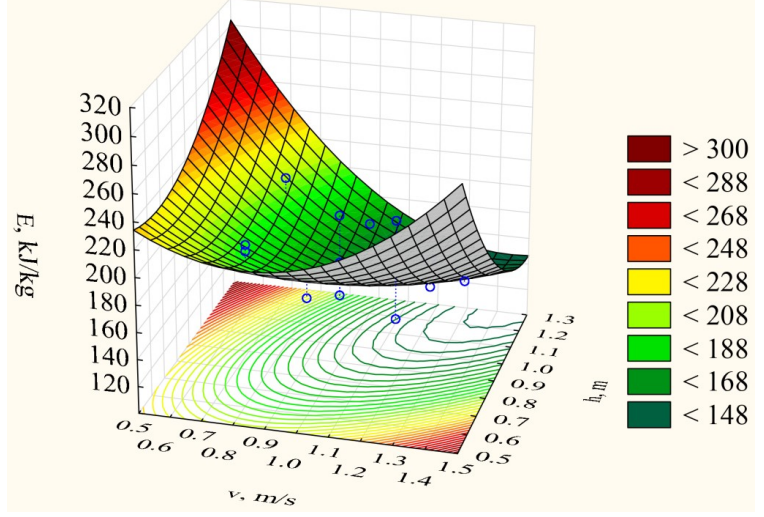

Fig. 6. Response surface of specific energy cost depending on the air velocity and the height of the blown zone

According to the formula:

$$
Y=b_{0}+\sum b_{i} x_{i}+\sum b_{i k} x_{i} x_{k}+\sum b_{i i} x_{i}^{2},
$$

where $b_{0}$ is a free term of the equation equal to the average response, provided that the factors under consideration are at average, "zero" levels; $i, k$ - factor indices;

$b_{i}$ - coefficients for linear terms;

$b_{i k}$ - coefficients of two-factor interactions, showing how much the degree of influence of one factor changes when the value of other changes;

$b_{i i}$ - coefficients of quadratic effects that determine the nonlinearity of the output parameter from the factors under consideration. 
The system of equations for determining $b_{0}$ and $b_{1}$ to calculate specific energy costs takes the form:

$$
\begin{aligned}
& 1.51=b_{0}+138.45 b_{1} ; \\
& -0.46=b_{0}+221.82 b_{1},
\end{aligned}
$$

where 138.45 is the best value for $y_{1}(\%) ; 221.82$ is the worst value for $y_{1}(\%)$.

Hence $b_{0}=4.7815$ and $b_{1}=-0.0236$.

There are one-way restrictions on output parameters of the form $Y \leq Y \max$ or $Y \geq Y$ min. An acceptable form of converting $Y$ to $d$ is an exponential dependence:

$$
d=\exp \left[-\exp \left(-Y^{\prime}\right)\right]
$$

where

$$
Y^{\prime}=b_{0}+b_{1} Y
$$

Particular functions take the form:

$$
d_{1}=\exp \left[-\exp \left(4.7815-0.0236 \cdot y_{1}\right)\right]
$$

The values of the particular desirability functions for all points in the plan, defined from (1) to (3), are given in Table 3.

Table 3

Values of particular functions and generalized desirability function of each experiment

\begin{tabular}{|c|c|c|c|c|c|}
\hline Experiment No. & $\mathrm{X}_{1}$ & $\mathrm{X}_{2}$ & $\mathrm{X}_{3}$ & $d_{1}$ & $D$ \\
\hline 1 & -1 & -1 & -1 & 0.376313 & 0.376 \\
\hline 2 & -1 & -1 & 1 & 0.376699 & 0.377 \\
\hline 3 & -1 & 1 & -1 & 0.279602 & 0.280 \\
\hline 4 & -1 & 1 & 1 & 0.381641 & 0.382 \\
\hline 5 & 1 & -1 & -1 & 0.529702 & 0.530 \\
\hline 6 & 1 & -1 & 1 & 0.156151 & 0.156 \\
\hline 7 & 1 & 1 & -1 & 0.128019 & 0.128 \\
\hline 8 & 1 & 1 & 1 & 0.010617 & 0.011 \\
\hline 9 & -1.682 & 0 & 0 & 0.422907 & 0.423 \\
\hline 10 & 1.682 & 0 & 0 & 0.109356 & 0.109 \\
\hline 11 & 0 & -1.682 & 0 & 0.467557 & 0.468 \\
\hline 12 & 0 & 1.682 & 0 & 0.133141 & 0.133 \\
\hline 13 & 0 & 0 & -1.682 & 0.277623 & 0.278 \\
\hline 14 & 0 & 0 & 1.682 & 0.083424 & 0.083 \\
\hline 15 & 0 & 0 & 0 & 0.035435 & 0.035 \\
\hline 16 & 0 & 0 & 0 & 0.035435 & 0.035 \\
\hline 17 & 0 & 0 & 0 & 0.035435 & 0.035 \\
\hline 18 & 0 & 0 & 0 & 0.035435 & 0.035 \\
\hline
\end{tabular}

The generalized desirability function $D$ takes a minimum value in experiment 8 ; it is 0.011 .

\section{2. The rationale for chamber height}

Taking into consideration the results of the construction of response surfaces according to the dependence of specific energy costs on the height of the blown chamber, air temperature, air velocity (Fig. 5,7), it can be concluded that the rational option would be to take the height of the blown chamber at the level of $1 \mathrm{~m}$. Fig. 9 shows a ternary plot that makes it possible to determine the optimal ratio of three factors to the resulting factor. Thus, the required height of the chamber for the modes of the optimal active ventilation process is justified.
Ternary Graph of E, $\mathrm{kJ} / \mathrm{kg}$ against $\mathrm{v}, \mathrm{m} / \mathrm{s}$ and $\mathrm{T},{ }^{\circ} \mathrm{C}$ and $\mathrm{h}, \mathrm{m}$ Spreadsheet $75 \mathrm{v}^{*} 18 \mathrm{c}$

$\mathrm{E}, \mathrm{kJ} / \mathrm{kg}=1.5709 \mathrm{E} 6{ }^{*} \mathrm{x}+487.9303 * \mathrm{y}+1.4943 \mathrm{E} 6 * \mathrm{z}-1.5992 \mathrm{E} 6 * \mathrm{x} * \mathrm{y}-$ $-4.4124 \mathrm{E} 6 * \mathrm{x} * \mathrm{z}-1.5137 \mathrm{E} 6 * \mathrm{y} * \mathrm{z}$

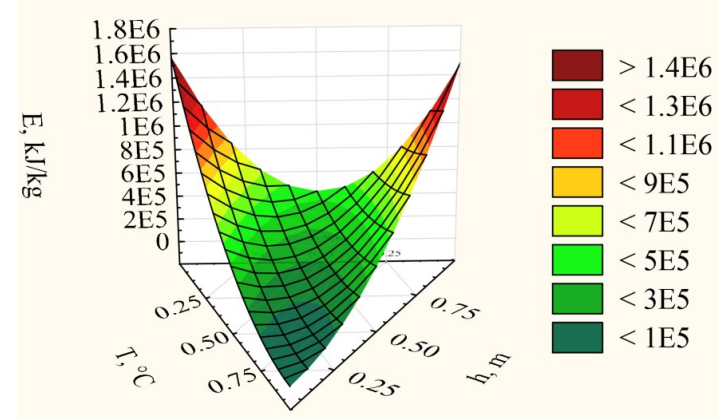

Fig. 7. Ternary plot $E, \mathrm{~kJ} / \mathrm{kg}$, depending on the height of the blown chamber, the speed of the supplied air, and its temperature

The ternary plot in Fig. 8 shows the dependence of specific costs $(E, \mathrm{~kJ} / \mathrm{kg})$ on airflow velocity $(v, \mathrm{~m} / \mathrm{s})$, temperature $\left(T,{ }^{\circ} \mathrm{C}\right)$, and chamber height $(h, \mathrm{~m})$. Since we have restrictions on the temperature, the optimal height of the chamber is $75 \%$ of the maximum 1.2 in the plan, i.e. $0.9-1 \mathrm{~m}$.

Thus, the assumptions about the rationality of the height of the blown chamber of 1 meter are confirmed.

\section{D Surface: Var3 vs. Var2 vs. Var1}

Temperature inside the grain $=14.7944+1.0509 * \mathrm{x}-0.0384 * \mathrm{y}+$ $+0.0019 * x * x-0.0049 * x * y+0.0005 * y * y$

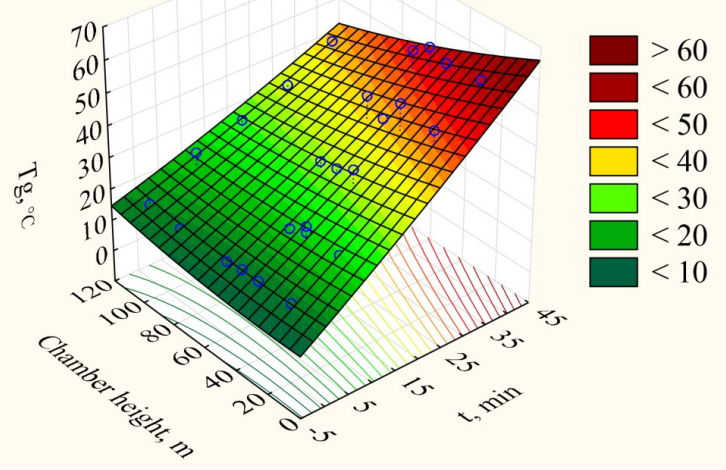

Fig. 8. The response surface of the grain temperature depending on the time of the grain at different chamber heights

The temperature inside the grain was measured at different chamber heights to determine the uniformity of the warm air supply and the uniformity of the distribution in the intergrain space. The surface shows that when heat air is supplied, the grain is heated over $15-25$ minutes to a temperature of $40{ }^{\circ} \mathrm{C}$.

6. Discussion of the study results on determining the structural parameters and drying modes by the method of active ventilation

Based on our study, it can be concluded that the height of the blown zone is important for active ventilation.

The selected height of the blown zone is more effective because the residence time of grains in the warm airflow is 
longer. Consequently, energy costs at the proper speed and temperature would be minimal (Fig. 5).

Our unit differs from existing installations by the original design of the system for supplying hot and removing the heat carrier used. In particular, a vertical gas distribution pipe with a mesh surface ensures an even distribution of hot heat carrier over the entire height of the installation, and the spiral shape of the suction pipe ensures quick and effective removal of the spent heat carrier along the entire height of the blown zone (Fig. 3).

The results of this study are reproducible and checked for the adequacy of the model; the desirability function has been built, which confirms the sufficiency of our calculations.

When conducting AGV, it should be considered that the incorrect choice of a rational technique and insufficient consideration of the state of the grain lead to an adverse effect on grains. The temperature of the working air during drying must be monitored and its rational value determined depending on the conditions for ensuring an even distribution of heated air. The temperature of the grain when drying by active ventilation should not exceed $45^{\circ} \mathrm{C}$. Overheating the grain leads to a deterioration in the quality of gluten up to its complete denaturation; the activity of enzymes decreases (Fig. 8).

When cooling grain by active ventilation, the air temperature is usually taken to be equal to the ambient temperature. With artificial cooling, the air must have low humidity since moisture from the intergrain space passes into the air and is extracted into the atmosphere.

Thus, according to [14], in the USA, only $1.8 \%$ of corn in grain is dried using low-temperature drying; using high-temperature drying and cooling inside the dryer $-43.5 \%$, while up to $50 \%$ of all grain is dried using a high-speed method that includes high-temperature drying followed by thermostating and active ventilation.

Studies [15-17] report data on an increase in the productivity of dryers when working with this technology by $40 \%$, fuel savings of up to $20-25 \%$, and $30 \%$ of electricity, specific fuel consumption is reduced to $3,350-3,770 \mathrm{~kJ} / \mathrm{kg}$ of evaporated moisture, cracking and the number of broken grains are reduced. There are data [10] on the use of high-speed two-stage drying technology in Russia where the implementation of new solutions and technological procedures made it possible to increase the productivity of grain dryers by $33-38 \%$ when the grain with an initial temperature of $50-60{ }^{\circ} \mathrm{C}$ and humidity of $16.0-16.5 \%$ was cooled after a $6-8$-hour aging at active ventilation units in a layer up to $2 \mathrm{~m}$ thick, at an air filtration rate of $0.1 \mathrm{~m} / \mathrm{s}$. The specific drying costs for mine-type direct-flow and recirculation dryers, according to the data, vary in the range of 4,750-6,100 and 3,900-5,150 kJ/kg.

The results of our studies show that the use of active ventilation in the processing of grain masses is an effective method while there is an issue related to reducing energy costs. However, the currently operated plants for active grain ventilation do not take into consideration all the complexities of the process and do not make it possible to comply with rational processing regimes, which affects the quality of the grain. Therefore, the task to devise scientifically based modes of active grain ventilation and its equipment structure is of great importance.

\section{Conclusions}

1. It has been established that with an insufficient amount of air pumped by a fan into the bulk grain, the grain cools very slowly while sweating and moistening of the upper horizons of the grain mound are often observed. The higher the moisture content of the grain, the more air must be supplied to the grain mound. This means that the air velocity $(\mathrm{m} / \mathrm{s})$ is the main parameter in cooling the sites of self-heating of the grain mass during storage.

2. The following installation parameters should be considered optimal: the height of the blown zone is $1 \mathrm{~m}$, while the airspeed is $1.2 \mathrm{~m} / \mathrm{s}$. In turn, in order for specific energy costs to be minimal, the air temperature should be about $80{ }^{\circ} \mathrm{C}$.

\section{References}

1. Mirovoy rynok zerna i prodovol'stvennoe obespechenie naseleniya zemli. Available at: http://www.vspmr.org/information/expertopinion/mirovoy-rinok-zerna-i-prodovoljstvennoe-obespechenie-naseleniya-zemli.html

2. Hemis, M., Watson, D. G., Gariépy, Y., Lyew, D., Raghavan, V. (2019). Modelling study of dielectric properties of seed to improve mathematical modelling for microwave-assisted hot-air drying. Journal of Microwave Power and Electromagnetic Energy, 53 (2), 94-114. doi: https://doi.org/10.1080/08327823.2019.1607491

3. Vasil'ev, A. N., Budnikov, D. A., Grachyova, N. N., Severinov, O. V. (2016). Sovershenstvovanie tekhnologii sushki zerna v plotnom sloe s ispol'zovaniem elektrotekhnologiy, ASU i modelirovaniya protsessa. Moscow: FGBNU FNAK VIM, 176. Available at: http:// xn--80aqa2d.xn--p1ai/files/690018a8-7ab4-413d-9f82-b5c6dbf497d9.pdf

4. Vasiliev, A. N., Ospanov, A. B., Budnikov, D. K., Karmanov, D. K., Salginbayev, D. B., Vasilyev, A. A. (2016). Controlling reactions of biological objects of agricultural production with the use of electrotechnology. International Journal of Pharmacy \& Technology, 8 (4), 26855-26869.

5. Han, F., Zuo, C., Wu, W., Li, J., Liu, Z. (2012). Model Predictive Control of the Grain Drying Process. Mathematical Problems in Engineering, 2012, 1-12. doi: https://doi.org/10.1155/2012/584376

6. Vasilyev, A. A., Tsimba, A., Vasilyev, A., Ershova, I., Belov, A. (2019). Mathematical and computer models of the change of the parameters of the grain layer during the movement of the grain through the microwave and convection zone. Amazonia Investiga, 8 (19), 138-148. Available at: https://amazoniainvestiga.info/index.php/amazonia/article/view/213

7. Morozov, M. S., Morozov, C. M., Reut, V. A. (2016). Mikrovolnovaya ustanovka dlya sushki zerna. Molodoy ucheniy, 30 (134), 83-86. Available at: https://moluch.ru/archive/134/37631/

8. Afonkina, V. A., Zakhakhatnov, V. G., Mayerov, V. I., Popov, V. M. (2016). On the question of process control combined grain drying. Mordovia University Bulletin, 26 (1), 32-39. doi: https://doi.org/10.15507/0236-2910.026.201601.032-039 
9. Sorochinskiy, V. F., Dogadin, A. L. (2018). Kontrol' protsessa sushki zerna po parametram otrabotavshego agenta sushki. Hleboprodukty, 3, 49-53. Available at: https://vniiz.org/science/publication/article-307

10. Podgorodetskiy, O. A. (2020). K voprosu snizheniya energozatrat v tekhnologii dvuhstadiynoy sushki zerna. Hranenie i pererabotka zerna. Available at: https://agroserver.ru/articles/1147.htm

11. Golubkovich, A. V., Lukin, I. D. (2018). High Humidity Grain Periodic Drying. Agricultural Machinery and Technologies, 12 (2), 9-13. doi: https://doi.org/10.22314/2073-7599-2018-12-2-9-13

12. Golubkovich, A. V., Pavlov, S. A., Lukin, I. D. (2016). Study of pulse drying of grain in the S-30 dryer. Tractors and Agricultural Machinery, 83 (6), 27-30.

13. Vasiliev, A. N., Severin, O. V. (2015). Structural scheme of model of drying grain in sectional setups of active aeration. International Research Journal, 8 (39), 22-25. Available at: https://research-journal.org/agriculture/strukturnaya-sxema-modeli-sushki-zernav-sekcionnyx-ustanovkax-aktivnogo-ventilirovaniya/

14. Hansen, R. C., Berry, M. A., Keener, H. M., Gustafson, R. J. (1996). Current Grain Drying Practices in Ohio. Applied Engineering in Agriculture, 12 (1), 65-69. doi: https://doi.org/10.13031/2013.25440

15. Bastron, T. N., Chirukhina, N. M. (2012). Energy saving modes of drying the oats by means of forced aeration. Vestnik KrasGAU, 4, 192-197. Available at: https://cyberleninka.ru/article/n/energosberegayuschie-rezhimy-sushki-ovsa-aktivnym-ventilirovaniem

16. Kretov, I. T., Kravchenko, V. M., Drannikov, A. V. (2003). Sravnitel'naya otsenka protsessa sushki sveklovichnogo zhoma topochnymi gazami i peregretym parom. Izvestiya vuzov. Pischevaya tekhnologiya, 1, 44-46. Available at: https://cyberleninka.ru/ article/n/sravnitelnaya-otsenka-protsessa-sushki-sveklovichnogo-zhoma-topochnymi-gazami-i-peregretym-parom

17. Sorochinskiy, V. F. (2015). Povyshenie effektivnosti konvektivnoy sushki zerna. Saarbrücken: LAP LAMBERT, 116. Available at: https://www.lap-publishing.com/catalog/details/store/gb/book/978-3-659-74511-9/povyshenie-effektivnosti-konvektivnojsushki-zerna 